\title{
СТРУКТУРА СООБЩЕСТВ МЕЛКИХ МЛЕКОПИТАЮЩИХ БИОТОПОВ РАЗНОЙ СТЕПЕНИ АНТРОПОГЕННОЙ ТРАНСФОРМАЦИИ ЛЕСОПАРКОВОЙ ЗОНЫ НОВОСИБИРСКОГО АКАДЕМГОРОДКА
}

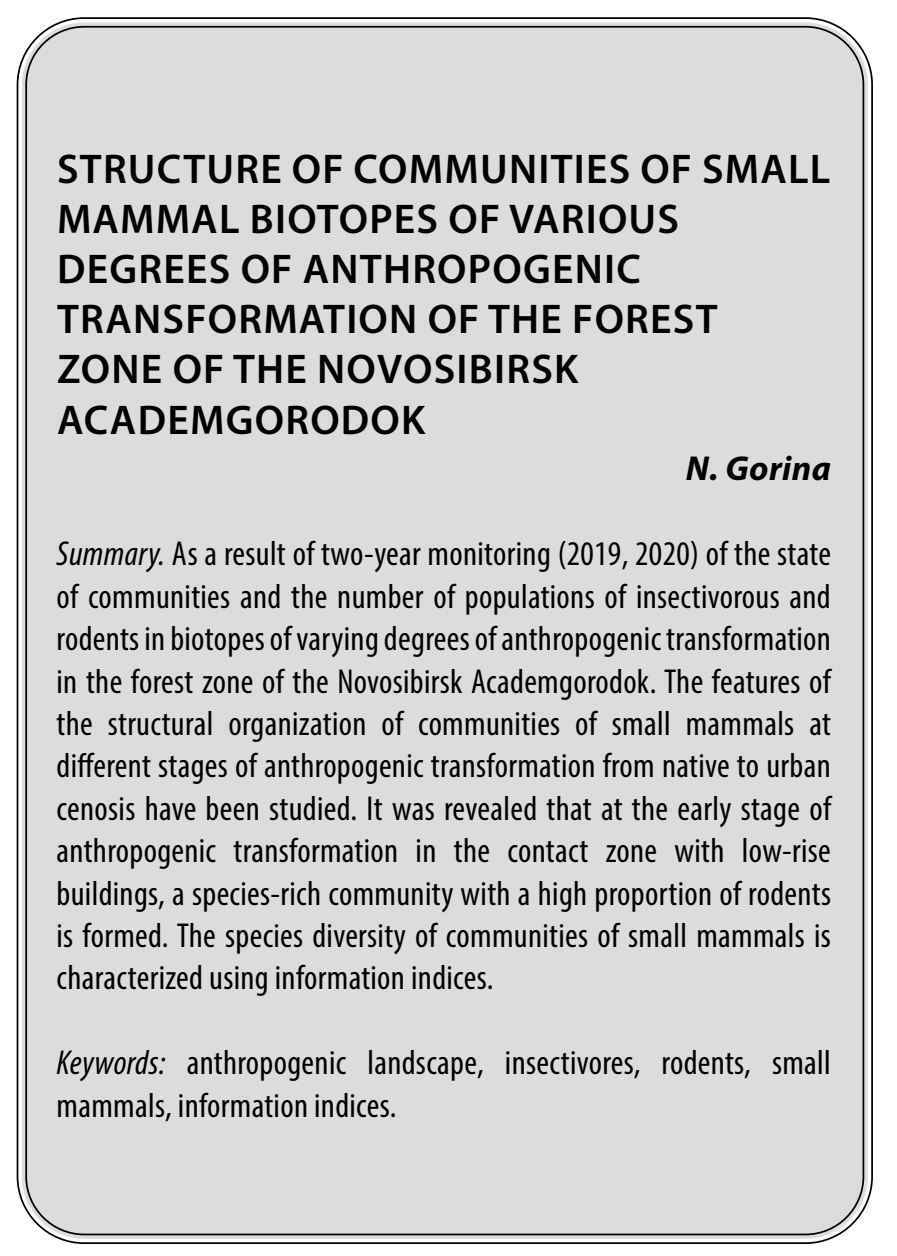

B отечественной и зарубежной литературе накоплен обширный материал по реакциям мелких млекопитающих на антропогенную трансформацию среды. Вместе с тем, подавляющее большинство подобных работ направлено на оценку антропогенной трансформации ландшафтов, обусловленной строительством и функционированием промышленных и сельскохозяйственных объектов. Значительно меньше известно о процессах, происходящих при освоении территории в ходе жилищного строительства. Имеющиеся данные касаются, главным образом, многоэтажной застройки. Работы по изучению мелких млекопитающих в районах дачной и коттеджной постройки являются единичными (Пястолова, Нуртдинова, 2008). Подавляющее число биоиндикационных исследований начинается уже после коренных преобразований ландшафтов.
Горина Наталья Дмитриевна

Аспирант, Новосибирский Государственный Аграрный Университет ndgorina@mail.ru

Аннотация. В результате двухлетнего мониторинга (2019, 2020 гг.) состояния сообществ и численности популяций насекомоядных и грызунов биотопов разной степени антропогенной трансформации на территории лесной зоны Новосибирского Академгородка. Изучены особенности структурной организации сообществ мелких млекопитающих на разных этапах антропогенной трансформации от нативной до урбоценоза. Выявлено, что на раннем этапе антропогенной трансформации в зоне контакта с малоэтажной застройкой формируется богатое видами сообщество с высокой долей численности грызунов. Видовое разнообразие сообществ мелких млекопитающих охарактеризовано с помощью информационных индексов.

Ключевые слова: антропогенный ландшафт, насекомоядные, грызуны, мелкие млекопитающие, информационные индексы.

Работ по мониторингу процесса этих преобразований на всех его этапах (от нативной экосистемы до урбоценоза) практически нет. На территории Новосибирской области запущен процесс упорядочивания малоэтажной комплексной застройки. Наша работа посвящена исследованиям по изучению видовой структуры и биоразнообразия сообществ мелких млекопитающих, обитающих на территориях с различной степенью антропогенной трансформации на всех этапах освоения в ходе жилищного строительства. В этом контексте была поставлена цель работы - выявить различия структуры и численности сообществ мелких млекопитающих биотопов в процессе малоэтажной застройки и на более поздних этапах антропогенной трансформации. Под биотопом мы понимаем территорию естественной растительности, на котором происходит отлов зверьков. 


\section{Материалы и метолика}

На изучаемой территории были выделены 4 типа биотопов лесопарковой зоны Новосибирского Академгородка, различающихся по степени антропогенной трансформации: контрольный участок естественной растительности - «лес» и 3 экспериментальных участка: в зоне контакта с малоэтажной застройкой на начальном этапе жилищного строительства - «стройка», на границе с дачным товариществом - «дачи» и лесополоса между полями проса - «поле». Участки расположены относительно недалеко друг от друга, радиус рассматриваемой территории составляет не более 5 км. В зависимости от последствий деятельности людей на исследуемые ландшафты в процессе освоения территорий, определена последовательность биотопов по степени антропогенной трансформации в порядке убывания: стройка, дачи, поле, лес.

Стройка еще не завершена, за последние 2 года коттеджи, проложены автомобильные дороги, происходит освоение новых территорий для дальнейшего строительства.

Садово-дачное товарищество сформировалось в 80-х годах прошлого века, исследуемый биотоп находится в 5 м. от границ дач с лесной зоной Новосибирского Академгородка.

Поле - лесная формация на стыке с полями.

Естественная растительность представлена березовым лесом с примесью осины. Береза повислая (Betula pendula) отличается светолюбием, быстрым ростом молодняка, нетребовательностью к почве и относительной морозоустойчивостью. Осина обыкновенная (Populus tremula) предъявляет большие требования к почве и более светолюбива, поэтому меньше распространена.

Объект исследований - довольно значимая в биоценотическом плане группа мелких млекопитающих: землеройки и мышевидные грызуны. На исследуемой территории добыто 19 видов мелких млекопитающих, которые по степени доминирования в суммарных отловах располагаются следующим образом: обыкновенная бурозубка (Sorex araneus L.) 0,54, полевка-экономка (M.oeconomus Pall.) 0,08, полевка красная (Myodes rutilus Pall.) 0,05, мышь полевая (Apodemus agrarius Pall.) 0,05, полевка пашенная (Microtus agrestis Pall.) 0,04, малая бурозубка (Sorex minutus L.) 0,04, обыкновенная полевка (Microtus arvalis Pall.) 0,03, лесная мышовка (Sicista betulina Pall.) 0,03, средняя бурозубка (Sorex caecutiens Laxmann) 0,03, рыжая полевка (Myodes glareolus Pall.) 0,03, красно-серая полевка
(Myodes rufocanus Pall.) 0,03, равнозубая бурозубка (Sorex isodon Turov) 0,02, обыкновенная кутора (Neomys fodiens Pennant) 0,02, сибирский крот (Talpa altaica Nikolsky) 0,02, мышь-малютка (Micromys minutus Pall.) 0,02, сибирская белозубка (Crocidura sibirica Dukelsky) 0,01, тундряная бурозубка (Sorex tundrensis Merriam) 0,001, восточноазиатсукая мышь (Apodemus peninsulae Thomas) 0,001, полевка узкочерепная (Microtus gregalis Pall.) 0,001. В работе использованы материалы, собранные автором в период за 2 года (2019 г.,2020г). Все материалы объединяют использование единых методик их сбора и обработки. Отловы проводились с помощью стандартных ловчих канавок 50 м длиной с 5 цилиндрами, вкопанными с интервалом 10 м (Наумов, 1955) в единые сроки с 18 июня по 30 августа и проверялись ежедневно утром. Для обеспечения сравнимости данных, полученные результаты учетов пересчитывались в единицы относительной численности (число особей на 100 цилиндросуток - далее ц.с.). За исследуемый период было отработано 3850 ц.с., отловлено 392 экземпляров отряда Eulipotyphla и 242 отряда Rodentia. Bсе пойманные экземпляры подвергались стандартной зоологической обработке.

Для характеристики численности видов применена бальная оценка на основании индекса доминирования (Беклемишев,1961), который отражает соотношения видов в сообществе (и.д.,\%): 4 - доминирующий (10> и.д.), 3 - обычный $(10>$ и.д. < 3), 2 - редкий $(3>$ и.д. < 1), 1 - единичный (1 > и.д.).

Для комплексной оценки количественных отношений между видами и уровнем видового разнообразия в сообществах мелких млекопитающих нами использованы информационные показатели. В качестве мер разнообразия и выравненности применены информационные индексы. Индекс Симпсона $D=1 / \Sigma p^{2}{ }_{i}$, индекс выравненности Симпсона $E=D / S$, индекс Шеннона $H$ $=\sum p_{i} \ln p_{i}$ индекс выравненности Шеннона $J=H / \ln S$, где $p_{i}$ - доля $i$ - вида в суммарной численности, $S-$ видовое богатство.

Индекс Симпсона обычно зависит от числа видов в сообществе и их соотношения, как правило, он сильнее других реагирует на перестройку в структуре доминирования сообществ мелких млекопитающих и, как следствие, наиболее чувствителен к изменению доминирования, в том числе и под влиянием антропогенных факторов. Индекс Шеннона также зависит от совокупности значений доли каждого вида в сообществе. Он не меняется, если число видов и их относительные доли постоянны. Поэтому изменения значений индекса, особенно в сторону уменьшения, указывают на нарушение структуры доминирования сообщества, выпадения из него отдельных видов, т.е. на утрату устойчивости 
Таблица 1. Бальная оценка численности видов мелких млекопитающих на разных типах биотопов лесопарковой зоны Новосибирского Академгородка, различающихся по степени антропогенной трансформации.

\begin{tabular}{|l|l|l|l|l|}
\hline Вид & Стройка & Дачи & Поле & Лес \\
\hline Крот сибирский & 2 & 2 & 3 & 1 \\
\hline Бурозубка обыкновенная & 4 & 4 & 4 & 4 \\
\hline Бурозубка тундряная & - & 1 & - & - \\
\hline Бурозубка средняя & 1 & 2 & 2 & 2 \\
\hline Бурозубка малая & 2 & 3 & 3 & 3 \\
\hline Бурозубка равнозубая & 3 & 2 & 1 & - \\
\hline Белозубка сибирская & 1 & 2 & 1 & 1 \\
\hline Кутора обыкновенная & 2 & 3 & - & 2 \\
\hline Лесная мышовка & 1 & 3 & 1 & 2 \\
\hline Мышь полевая & 2 & 3 & 2 & 3 \\
\hline Мышь восточноазиатская & 1 & - & - & - \\
\hline Мышь-малютка & 2 & 1 & - & 2 \\
\hline Полевка красно-серая & 2 & 2 & 2 & 1 \\
\hline Полевка рыжая & 3 & - & 3 & 1 \\
\hline Полевка красная & 1 & 2 & 4 & 2 \\
\hline Полевка-экономка & 4 & 1 & 3 & 4 \\
\hline Полевка пашенная & 3 & 2 & 2 & 2 \\
\hline Полевка обыкновенная & 2 & 3 & 1 & 1 \\
\hline Полевка узкочерепная & - & 99 & - & - \\
\hline отловлено экз. & 186 & 980 & 173 & 176 \\
\hline $\begin{array}{l}\text { Обработано } \\
\text { (цилиндро-суток) }\end{array}$ & 950 & $(8 / 9)$ & 980 \\
\hline Количество видов (насекомоядные/грызуны) & 17 & $(7 / 10)$ & 17 & $(6 / 8)$ \\
\hline
\end{tabular}

Виды: 4 - доминирующий, 3 - обычный, 2 - редкий, 1 - единичный, «-»- вид отсутствует в уловах.

сообщества (Бигон и др.,1989, Мэгарран, 1992, Литвинов и др., 1998, 2010).

\section{Результаты и обсужление}

Состав фауны и структура населения мелких млекопитающих разных типов биотопов лесопарковой зоны Новосибирского Академгородка.

Основу фауны мелких млекопитающих лесопарковой зоны Новосибирского Академгородка составляют лесные виды насекомоядных и грызунов, биотопическая приуроченость которых тесно связана с принадлежностью к различным фауногенетическим группам (Кучерук, 1959; Кулик, 1972; Шварц,1989). Фауногене- тическая связь и биотопическая приуроченность насекомоядных к разреженным лиственничным лесам с развитым травянистым покровом обеспечивают их относительно высокую численность и абсолютное доминирование в сообществах.

Многочисленную группу составляют виды, фауногенетически связанные с лесами Северной Азии. Таежный или сибирский фаунистический комплекс представлен 7 видами: равнозубая, тундряная, средняя, плоскочерепная бурозубки, сибирский крот, красная, красносерая полевки.

Виды, по происхождению связанные с хвойно-широколиственными лесами третичного периода, состав- 


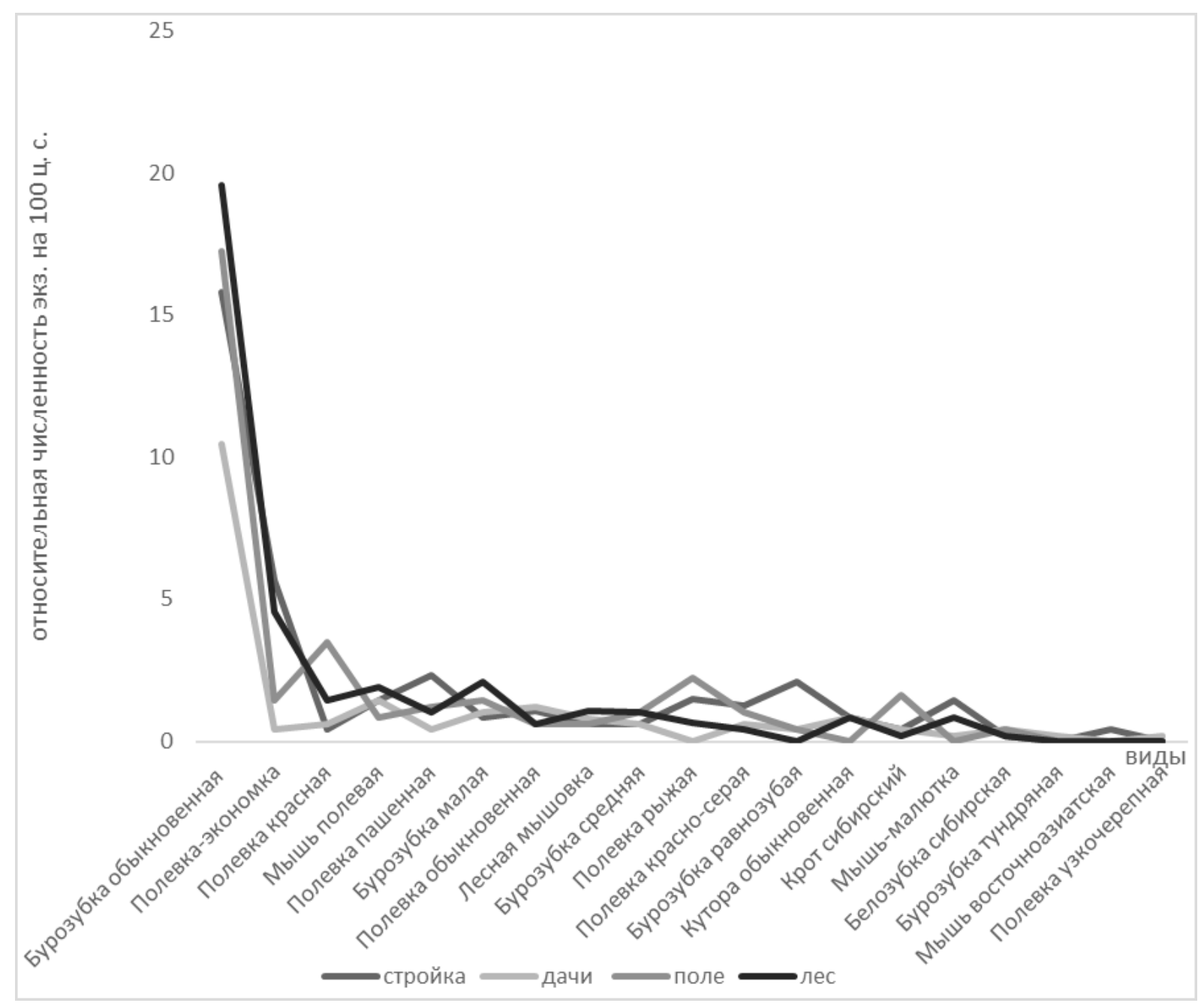

Рис. 1. Средняя относительная численность мелких млекопитающих на исследуемых биотопах за период 2019-2020 г.г. (число особей на 100 ц.с.)

ляют следующую группу: белозубка сибирская, лесная мышовка, обыкновенная и рыжая полевки, восточноазиатская мышь.

Еще одну группу в составе фауны образуют западные палеаркты: бурозубка обыкновенная, мышь-малютка, мышь полевая, полевка-экономка, пашенная полевка.

Бурозубка малая и кутора обыкновенная фауногенетически являются южными видами. Один вид - узкочерепная полевка, относится к тундростепным реликтовым видам.

Анализ видовой структуры населения мелких млекопитающих (табл. 1) и показатели их численности (рис. 1), предоставляют возможность выявить общие черты и характерные особенности этой группе животных в пределах исследуемых биотопов лесопарковой зоны Новосибирского Академгородка.
При анализе соотношения численности на всех исследуемых биотопах выделены специфические особенности, свойственные группировкам исследованных животных: в пределах всех типов биотопов доминирующим видом является бурозубка обыкновенная (рис. 1), так как численность насекомоядных превышает численность мышевидных грызунов в суммарных отловах на поле и в лесу примерно в 2, в садово-дачном товариществе (дачи) в 2,4 раза. Однако на экспериментальном участке строительства коттеджей, который соответствует раннему этапу антропогенной трансформации ландшафта (стройка), значительных различий этого показателя не обнаружено (рис. 2).

\section{Стройка}

Общее количество отловленных зверьков здесь самое высокое - 186 экз., зафиксирована более высокая численность мышевидных грызунов относительно чис- 


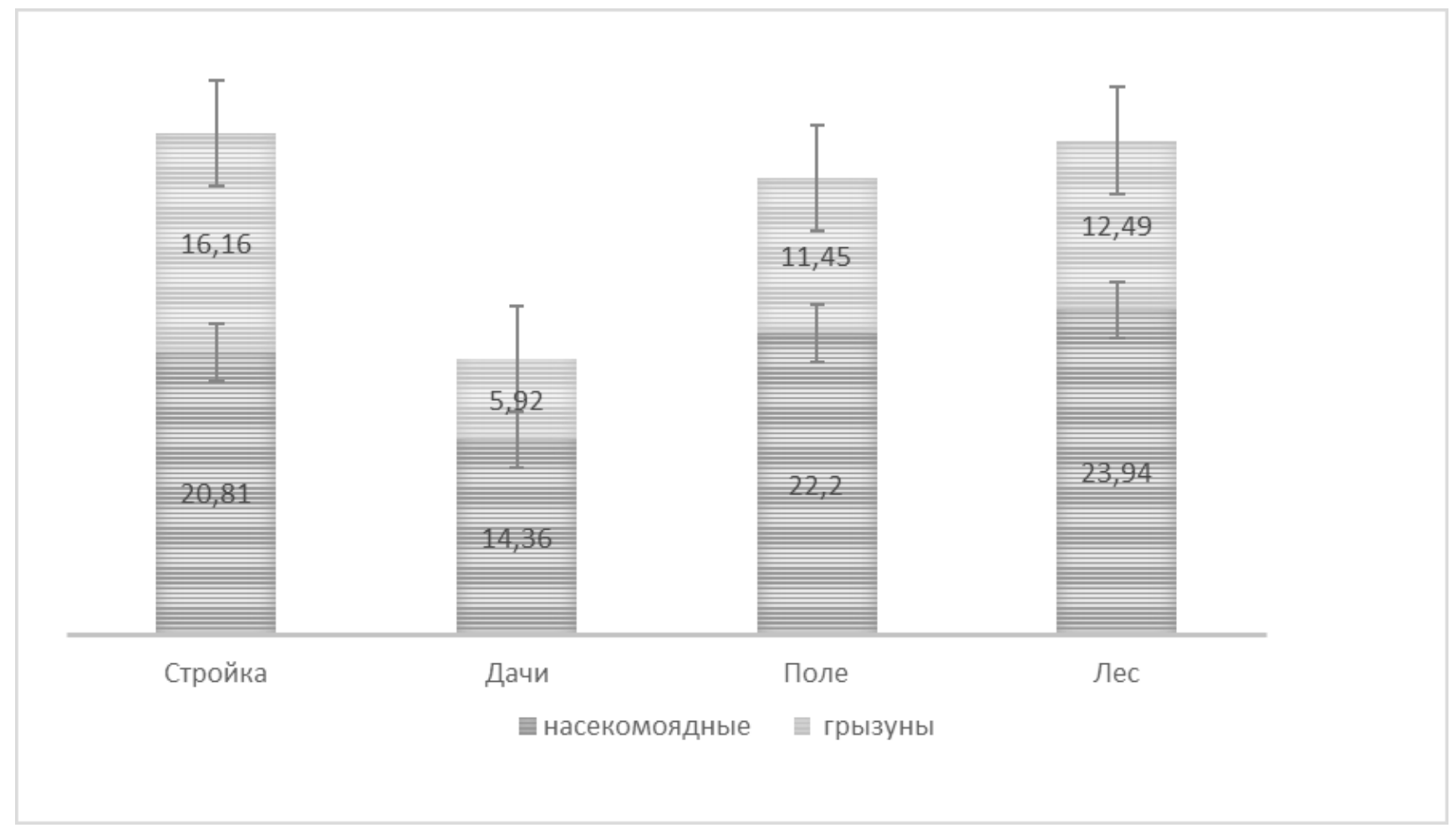

Рис. 2. Численность мелких млекопитающих на разных типах биотопов лесопарковой зоны Новосибирского Академгородка, различающихся по степени антропогенной трансформации за 2 года исследований, экз. на 100 ц.с.

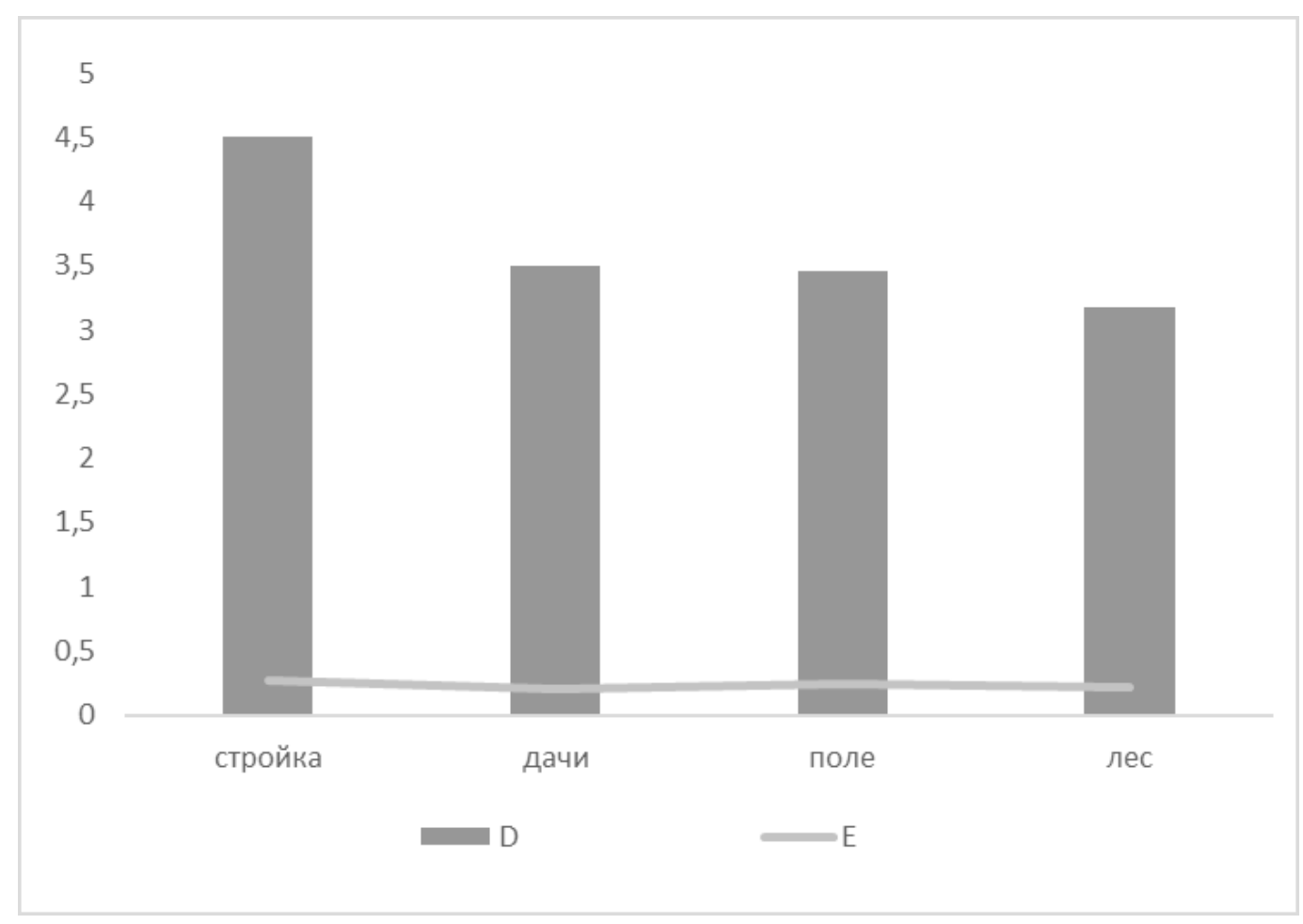

Рис. 3. Информационные индексы биоразнообразия Симпсона - D и индексы выравненности Симпсона - Е сообществ мелких млекопитающих биотопов 
ленности насекомоядных в суммарных отловах (рис. 2) в сравнении с аналогичными показателями на остальных биотопах. Видовое разнообразие сообщества мелких млекопитающих, в сравнении с таким же показателем на остальных биотопах - выше, как и значение индекса Симпсона (рис. 3).

Доминирующую группировку составляют обыкновенная бурозубка и полевка-экономка. Абсолютное доминирование первого вида определяется благоприятными условиями биотопа: микроклимат вырубок отличается от лесного более резкими колебаниями температурного режима, влажности. Такие условия сложились в результате малоэтажной застройки территории, сопровождающейся вырубкой, прокладкой дорог и т.п., как следствие вторичной сукцессией экосистемы. В условиях высокой освещенности начинает интенсивно разрастаться рудеральная растительность, в летне-осенний период здесь селится большое число объектов питания бурозубки обыкновенной. Для полевки - экономки, второго доминирующего вида, достаточное увлажнение и значительное развитие травянистого яруса, являются благоприятными условиями. Обычны равнозубая бурозубка, рыжая и пашенная полевки. Первый вид предпочитает места с хорошо развитым слоем подстилки, полевки тяготеют к влажным местам обитания, поселяются на зарастающих вырубках. Редки в составе сообщества виды, предпочитающие осветлённые и более открытые участки: мышь малютка, полевая мышь, полевка обыкновенная.

Достаточно быстрое изменение экосистемы в процессе застройки, разнообразие условий местообитания, по нашему мнению, определяют параметры видового разнообразия и сосуществование здесь более значительного числа видов мышевидных грызунов в пределах всех исследуемых участков. Исходя из вышеизложенного данное сообщество является полидоминантным, недостаточно выравненным, нарушенное. Имеет более равномерное распределение видов, что выражается в постепенном снижении долевого участия от доминантов к малочисленным видам и высокой суммарной численностью, что свидетельствует о благоприятных условиях для большинства видов. Обыкновенная бурозубка в отличие от сообщества леса не столь многочисленна и имеет сопоставимые показатели численности с другими видами.

\section{$\triangle$ ачи}

К особенностям, свойственным группе животных в пределах садово-дачного товарищества можно отнести: самую низкую численность и максимальное превышение в суммарных отловах насекомоядных относительно численности грызунов. Однако сооб- щество представлено 17 видами: 8 насекомоядных и 9 мышевидных грызунов, что характеризует достаточную емкость среды. Видовое разнообразие сообщества мелких млекопитающих соответствует значению индекса Симпсона 3,5. Абсолютно доминирует обыкновенная бурозубка, так как в отловах преобладают насекомоядные и данный вид является преобладающим по численности. Обычными являются: малая бурозубка, обыкновенная кутора, лесная мышовка, полевая мышь и обыкновенная полевка. Полевки: красная, пашенная, красно-серая не достигают значительной численности из-за скудости кормовой базы. Редкие насекомоядные: крот сибирский, сибирская белозубка, средняя и равнозубая бурозубки. Мышь - малютка и полевка-экономка единичны в отловах. Только здесь проникает в лесные местообитания узкочерепная полевка. Учитывая особенности, свойственные группировке исследованных животных на данной территории, такое сообщество является малочисленным, полидоминантным с преобладанием доли насекомоядных, невыравненное.

\section{Поле}

Количество отловленных зверьков возле поля достаточно высокий - 173 экз. Анализ бальной оценки численности видов мелких млекопитающих на поле выявил наименьшее их число - 14, из которых 6 насекомоядных и 8 видов мышевидных грызунов. Численность последней группы животных в суммарных отловах в 2 раза ниже насекомоядных. Это свидетельствует, что данное сообщество отличается не только видовым составом, но и структурой доминирования. Невысокое видовое разнообразие сообщества мелких млекопитающих соответствует значению индекса Симпсона 3,5. В составе сообщества доминируют обыкновенная бурозубка и красная полевка. Высокая численность красной полевки связана с предпочтениями к местообитаниям с достаточным количествам семян травянистых растений, грибов, ягод. Группировку обычных видов составляют сибирский крот, малая бурозубка, рыжая полевка и полевка-экономка. Высокая численность первых двух видов насекомоядных обеспечивается достаточной кормовой базой. Активизация насекомых вызвана более ранним сходом снега на поле и прогреванием почвы. Высокая численность именно малой бурозубки на данной территории можно объяснить, что она более насекомоядна, чем другие землеройки (Шефтель Б.И., 1990, Гусева. Т.Л. и др., 2014, Ивантер Э.В., Курхинен Ю.П., 2014,). Многочисленна полевка-экономка, которая тяготеет к опушкам. Распространение рыжей полевки хорошо согласуется с тем, что она тяготеет к участкам, занятым растительностью с элементами неморальной флоры (Виноградов, 2011). Высокая численность обыкновенной бурозубки определяет малочисленность средней бурозубки в отловах. Редки в со- 
ставе сообщества виды, тяготеющие к местообитаниям мезофитного типа - полевая мышь, красно-серая и пашенная полевки (Пузаченко Ю.Г., Кузнецов Г.В., 1998, Роговин К.А., 1999, Андреева Т.А., Окулова Н.М., 2009). Равнозубая бурозубка, белозубка сибирская, обыкновенная полевка и лесная мышовка единичны. Число видов, входящих в это сообщество в пределах нашего исследования, минимально, что определяется ограниченной биологической продуктивностью растительного покрова, маломощностью и бедностью почв на этой территории, их истощения в результате многолетнего аграрного оборота полей. Таким образом, на данной территории сложилось обедненное сообщество мелких млекопитающих с неравномерным ранговым распределением видов.

\section{^ec}

Показатели численности и анализ видовой структуры населения мелких млекопитающих на участках контроля (лес) и поля, позволяют выявить общие черты, свойственные этим группам животных на биотопах: количество отловленных экземпляров, количества видов насекомоядных и мышевидных грызунов, соотношение численности отловленных представителей отрядов, как 2:1 соответственно, вид-доминант - обыкновенная бурозубка, высокая численность малой бурозубки, редко встречается средняя бурозубка. Однако, следует обратить внимание на специфические особенности структуры доминирования насекомоядных на участке контроля: отсутствие равнозубной бурозубки, единичны экземпляры крота сибирского, редким является в составе сообщества вид, предпочитающий увлажненные местообитания - кутора обыкновенная. Анализ видовой структуры сообщества мышевидных грызунов контрольного участка - лес, отличается присутствием в отловах вида мышь-малютка, не зафиксированного на поле. Структура доминирования грызунов существенно отличается. Хотя доминирующий вид полевка - экономка, а полевая мышь - обычна в отловах, численность этого вида тоже существенна. Редкие в отловах виды: лесная мышовка, мышь-малютка, красная и пашенная полевки, неплохо представлены в сообществе леса. Единичны красно-серая, рыжая и обыкновенная полевки. Информационный индекс разнообразия Симпсона имеет достаточно высокий показатель, равный, несмотря на преимущество в численности насекомоядных (рис. 3). В целом структура доминирования характеризует сообщество мелких млекопитающих как полидоминантное, слабовыравненное, в незначительной степени нарушенное.

\section{Зак^ючение}

Фауна 4 типов биотопов лесопарковой зоны Новосибирского Академгородка, различающихся по степе- ни антропогенной трансформации, включает 19 видов мелких млекопитающих: 8 насекомоядных и 11 видов мышевидных грызунов, которые относятся к трем фауногенетически группам. Самая многочисленная группа хвойно-широколиственных лесов Евразии - 6 видов. Менее многочисленна североазиатская таежная группа - 4 вида. Единственным представителем тундростепной фауны грызунов является узкочерепная полевка. Абсолютным доминирующий вид в сообществах - обыкновенная бурозубка. Это хорошо согласуется с данными численности отловленных животных, среди которых в суммарных отловах преобладают насекомоядные. Из мышевидных грызунов доминируют в сообществах красная полевка и полевка-экономка. Различия в видовом составе и смена лидеров внутри этой группы определяют облик сообществ биотопов. Изменение видового состава сообществ экспериментальных участков в сравнении с контролем, связано с миграцией видов из сопредельных ландшафтов, что определяется условиями местообитания на биотопах, различающихся по степени антропогенной трансформации. В пределах контрольного участка, занятого березовым с примесью осины лесом, доминируют обыкновенная бурозубка и полевка-экономка, сообщество включает 15 видов: 6 - насекомоядных и $9-$ грызунов. В пределах участка поле, на разделительной лесополосе произрастают лиственные породы деревьев и кустарники, которые с трех сторон окружены полями, а одна сторона переходит в березово-лиственничный лес. Здесь доминируют обыкновенная бурозубка и красная полевка, число видов составляет 14: 6 - насекомоядных и 9 - грызунов. Участок, граничащим с дачно-садовом обществом, покрыт редким березовым лесом, окружен со всех сторон проселочными дорогами для проезда к дачам. Число видов 17: 8 - насекомоядных и 9 - грызунов, где доминирует обыкновенная бурозубка. На биотопе в зоне контакта с малоэтажной застройкой зарастающие рубки, рядом бетонированная автомобильная дорога. Число видов 17: 7 - насекомоядных и 10 - грызунов, доминируют обыкновенная бурозубка и полевка-экономка.

Взаиморасположение видов мелких млекопитающих в экологическом пространстве на различных по степени антропогенной трансформации ландшафтов биотопах, определяет параметры видового разнообразия сообществ биотопов, которые разделяются на четыре типа: 1) полидоминантное, слабовыравненное, с равным соотношением насекомоядных и грызунов (стройка); 2) малочисленное, полидоминантное с преобладанием доли насекомоядных, невыравненное (дачи); 3) обедненное с неравномерным ранговым распределением видов (поле); 4) полидоминантное, слабовыравненное, в незначительной степени нарушенное (лес). 
Проведенный комплексный анализ показал сходство формирования и пространственной изменчивости сообществ мелких млекопитающих на биотопах разной степени антропогенной трансформации лесной зоны Новосибирского Академгородка и особенности структурной организации сообществ. На раннем этапе антропогенной трансформации в зоне контакта с малоэтажной застройкой формируется богатое видами сообщество с высокой долей численности грызунов, относительно сообществ биотопа леса, а также сооб- ществ более поздних этапов антропогенной трансформации - биотопы поля и дач.

\section{Б^агоАарности}

Автор выражает благодарность Панову Виктору Васильевичу, к.б.н., сотруднику Институт систематики и экологии животных СО РАН, за помощь в определении видовой принадлежности отловленных зверьков.

\section{ЛИТЕРАТУРА}

1. Андреева Т.А., Окулова Н.М. Экологические предпочтения лесных полевок // Экология. 2009. № 2. С. 149-154.

2. Бигон М., Харпер Дж., Таунсенд К. Экология. Особи, популяции, сообщества. М. Мир, 1989, Т. 1, 667 с., Т. 2, 278 с.

3. Беклемишев В.Н., 1961. Термины и понятия, необходимые при количественном учете популяций эктопаразитов и нидиколов // 30ол. журн. Т. 40. № 2. C. 148-158.

4. В.В. Виноградов Структурная организация сообществ землероек (Soricidae) горных лесов южной части Средней Сибири | Вестн. Том. гос. ун-та. Биология. 2011. № 3 (15).

5. Гусева. Т.Л., Коросов А.В., Беспятова Л.А., Аниканова В.С. Многолетняя динамика биотопического размещения обыкновенной (SOREX ARANEUS, LINNAEUS1758) в мозаичных ландшафтах Карелии// Ученые записки Петрозаводского гос. ун-та., 2014, № 8. Т. 2 С. 13-20

6. Ивантер Э.В., Курхинен Ю.П. Влияние антропогенной трансформации лесных экосистем Восточной Фенноскандии на популяции малой и средней бурозубок// Принципы экологии. 2014. № 2. С. 21-25.

7. Кулик И.Л., 1972. Таежный фаунистический комплекс млекопитающих Евразии // Бюл. Моск. 06-ва испытателей природы. Отд. биол. Т. 77. Вып. 4. C. 11-24.

8. Кучерук В.В., 1959. Степной фаунистический комплекс млекопитающих и его место в фауне Палеарктики // География населения наземных млекопитающих и методы его изучения. М.; Л. С. 45-87.

9. Литвинов Ю.Н. и др. Элементы пространственной организации сообществ мелких млекопитающих Сибири.// Сообщества и популяции животных: морфологический и экологический анализ. Новосибирск-Москва: Товарищество научных изданий КМК, 2010. с. 17-51.

10. Литвинов Ю.Н., Панов В.В. Структурные связи как элемент биоразнообразия в сообществе грызунов Северной Барабы. // Успехи совр. биол. Т. 118, вып. 1, 1998, с. 103-110.

11. Литвинов Ю.Н., 2004. Влияние факторов различной природы на показатели разнообразия сообществ мелких млекопитающих // Успехи современной биологии. Т. 124. № 6. С. 612-621.

12. Мэгарран Э. Экологическое разнообразие и его измерение. М., Мир, 1992, 184 с.

13. Наумов, Н.П. Изучение подвижности и численности мелких млекопитающих с помощью ловчих канавок / Н.П. Наумов // Вопросы краевой, общей и экспериментальной паразитологии и медицинской зоологии. - М., 1955 - Т. 9. — С. 135-160.

14. Пузаченко Ю.Г., Кузнецов Г.В. Экологическая дифференциация грызунов сезонновлажных тропических лесов северного Вьетнама // Зоологический журнал. 1998. Т. 77, № 1. С. 117-132.

15. Пястолова 0.А. Нуртдинова Д.В. Динамика численности мелких млекопитающих на мелкомозаичной урбанизированной территории// материалы третьей научно-практической конференции «урбоэкосистемы: проблемы и перспективы развития». Ишим,2008

16. Роговин К.А. Экология сообществ родственных видов животных (подходы и методы исследований на примере наземных позвоночных) // Журнал общей биологии. 1999. Т. 60, № 4. С. 394-413

17. Шварц Е.А., 1989. Формирование фауны мелких грызунов и насекомоядных таежной Евразии // Фауна и экология грызунов. М.: Изд-во Мгу. Вып. 17. C. 115-143.

18. Шефтель Б.И. Анализ пространственного распределения землероек в средней Енисейской тайге // Экологическая ординация и сообщества. М.: Наука, 1990. C. 15-32. 